but this need be of only very short duration, since any event requiring a high-speed camera naturally lasts only a very short time. To test the practicability of the design of the proposed camera, an experimental model was constructed, in which the lens system and rotating prisms were not included. In spite of these omissions, quite good pictures were obtained at rates of 70,000 a second, and a series of pictures, taken at the rate of 64,000 per second, of a rifle bullet fired at and piercing an electric light bulb, is included in the paper, illustrating very clearly the capabilities of the camera.

\section{South African Museum : Report for 1945}

The Trustees' report of the South African Museum, Pretoria, stresses the unsatisfactory finanoial position of the Museum, and it is pointed out that this greatly handicaps the development of its educational and cultural services. An interesting analysis of attendance figures appears in the acting director's report. This shows that during the year, 118,103 white, 56,402 coloured, and 10,499 native adult members of the population visited the Museum. The same report makes note of a special exhibit illustrating soil erosion, and pleads for similar educational propaganda in other African museums. The report of the Department of Fishes and Marine Invertebrates records the catching in South African waters (for the first time) of an adult deal-fish (Trachypterus) $7 \mathrm{ft}$. in length. In the Department of Botany, Mr. G. J. Lewis carried out work in connexion with plants and allergic diseases in the Cape Peninsula. He also published illustrated descriptions of two new species of Iridaceæ (J.S.Afr. Bot., 11, 108 and 117).

\section{Lady Tata Memorial Trust}

THe Trustees of the Lady Tata Memorial Fund invite applications for grants and scholarships, open to workers of any nationality, for research in diseases of the blood, with special reference to leukæmia, in the academic year beginning on October 1, 1947. Grants of variable amount are made for research expenses or to provide scientific assistants to senior workers. Scholarships are awarded as personal remuneration; their normal value has been $£ 400$ a year for whole-time research. Applications must be submitted, before March 31, to the secretary of the Scientific Advisory Committee, c/o Medical Research Council, 38 Old Queen Street, Westminster, London, S.W.1

\section{Conference on Industrial Research}

THE Federation of British Industries is arranging a series of regional conferences on industry and research, the first of which will be held at Birmingham on March 25. The principal speakers will be Sir Edward Appleton, secretary of the Department of Scientific and Industrial Research ; Sir William Larke, chairman of the Industrial Research Committee of the Federation of British Industries ; and Sir Peter Bennett, chairman of the Midland Regional Council of the Federation. The general subject to be discussed will be the application of science by industry, and the part research can play in promoting industrial efficiency, exports, and a higher standard of living, with special reference to industrial problems in the Birmingham area. Special attention will also be given to the smaller manufacturing concern. Further information may be obtained from the F.B.I. Industrial Research Secretariat, 21 Tothill St., S.W.1.

\section{Announcements}

The Linnean Medal for 1947 of the Linnean Society of London has been awarded to Prof. Maurice Caullery of the University of Paris. The actual presentation of the medal will take place on May 24.

THE London, Midland and Scottish Railway announces that Mr. G. E. Wilson, chemist, Scientific Research Department, Glasgow, has been appointed chemist, Scientific Research Department, Crewe, in succession to the late Mr. W. Darey. Mr. E. A. Morris, senior assistant chemist, Scientific Research Department, Glasgow, will succeed Mr. G. E. Wilson at Glasgow.

THe following appointments have been made in the Colonial Services : J. L. Congdon, to be agricultural officer, Aden ; C. A. Lister, to be plant pathologist, Gold Coast ; W. E. M. Logan (assistant conservator of forests, Gold Coast), to be assistant conservator of forests, Kenya.

Dr. C. C. Adprson, lecturer in inorganic chemistry at University College, Nottingham, has been awarded the degree of D.Sc. of the University of Durham for a thesis on "A Study of Soluble Films at Liquid Surfaces".

ApPornTments to not more than four Imperial Chemical Industries Fellowships in the University of Cambridge will be made in the Easter Term, with tenure from October 1, 1947. The Fellowships have been established for original research in physics, chemistry, biochemistry, engineering, metallurgy, pharmacology, chemotherapy, or in a subject related to one of these subjects. Persons of either sex may be elected, and the annual stipend of a fellow will normally be $£ 600$. Applications must reach the Registrary, at the University Registry, Cambridge, by April 20.

THE Worshipful Company of Founders of the City of London awards fellowships, usually one a year, to provide facilities for advanced education to men who have already completed a course of training of university standard in chemistry, physics, metallurgy (more especially in connexion with molten metal) and allied sciences. There is no limitation to the nature of the course which may be selected; it might include research, a period in works or foreign $\theta x$ perience. The normal value of the fellowship is $£ 300$ a year, and it will be renewable for a second year and in special cases for a third year. Candidates should not be less than twenty-one years of age on September $\mathrm{l}$ of the year of application. Applications must be received not later than May 1 by the Clerk of the Worshipful Company of Founders, Founders' Hall, 13 St. Swithin's Lane, E.C.4, to whom all inquiries should be addressed.

Messrs. Elliott Brothers (London), Ltd., 72 Victoria Street, London, S.W.1, have transferred their research laboratory from Century Works, Lewisham, to Elstree Road, Borehamwood, Herts, where they have a modern building of $50,000 \mathrm{sq}$. $\mathrm{ft}$. floor area. A new organisation is being built up which will undertake the development of industrial and laboratory instruments and specialized equipment; also it will develop new techniques for the control of manufacturing processes. The laboratories are in the charge of Mr. J. F. Coales, formerly of the Admiralty Signal Establishment, where he was engaged on research into radio direction finding and later on the development of radar for gunnery purposes in H.M. ships. 